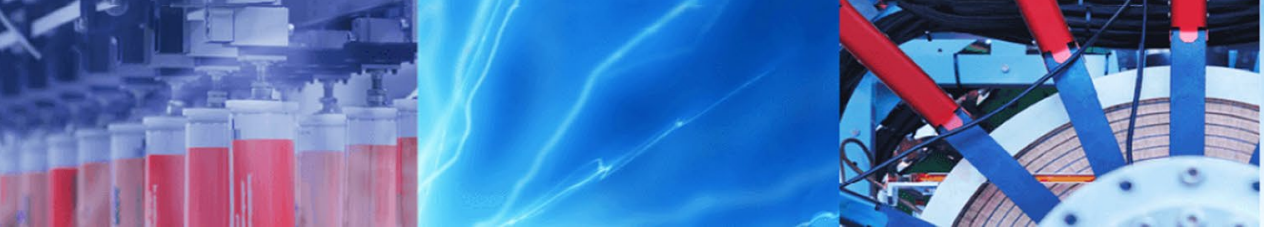

Research Article

\title{
Trace metal concentrations in a pristine Ramsar site: the Okavango Delta
}

\author{
O. Mogobe' ${ }^{1}$ W. R. L. Masamba ${ }^{2} \cdot$ K. Mosepele ${ }^{1}$
}

Received: 9 July 2019 / Accepted: 31 October 2019 / Published online: 12 November 2019

(c) Springer Nature Switzerland AG 2019

\begin{abstract}
Pristine aquatic environments are the preferred state for maintaining ecosystem integrity, supporting biodiversity and preserving human health. However, world ecosystems have been altered by anthropogenic activities which release chemical contaminants into the environment and threaten terrestrial and aquatic life. In order to protect water bodies from pollution, monitoring water quality indicators and levels of trace metals is critical. The Okavango Delta is regarded pristine, but concentrations of trace metals in the river have not been adequately studied. This study quantifies concentration of 10 trace metals, determines their spatiotemporal distribution and assesses associated health risks. Water samples were collected monthly between 2014 and 2017 from five sites and concentrations determined by ICP-OES. The results indicate that all metals studied were present at all study sites with a concentration in the order of $\mathrm{Fe}>\mathrm{Mn}$ $>\mathrm{Ni}>\mathrm{V}>\mathrm{Zn}>\mathrm{Pb}>\mathrm{Cd} \gg \mathrm{Cu}>\mathrm{Cr}>\mathrm{Co}$, a wide occurrence of metals reflecting a possible presence of mafic and ultramafic rocks in the catchment. Concentrations of trace metals were variable, but these were not statistically significant at $p \leq 0.05$, indicating a relatively uniform water composition. However, Fe occurred in distinctively higher concentrations compared to other metals. When compared with US EPA guidelines for freshwater ecosystems and WHO drinking water standard, mean concentrations of all metals except $\mathrm{Pb}$ were below EPA guidelines for freshwater ecosystems and WHO drinking water standard. The risk assessment revealed that none of the metals posed health risks to the communities that use river water as a direct drinking source. Continuous monitoring is necessary for the protection of human health and sustainability of the delta.
\end{abstract}

Keywords Okavango Delta · Pristine $\cdot$ Trace metals $\cdot$ Freshwater ecosystem $\cdot$ Health risk assessment

\section{Introduction}

Water resources are important for producing food, sustaining integrity of aquatic ecosystems and for protecting human health [1]. The Okavango Delta is regarded one of the most pristine inland deltas in Africa, a Ramsar site and a UNESCO world heritage site with a rich biological diversity $[2,3]$. The ecological and economic importance of this delta has prompted research in which the results have shown that the water quality of the system is suitable for maintaining ecosystem health $[2,4,5]$. Concentration of trace metals in surface water and the understanding of processes that drive their mobility and accumulation are important for effective management of aquatic systems. Most studies on water quality of the Okavango Delta employed basic water quality indicators such as temperature, $\mathrm{pH}$, electrical conductivity, turbidity and dissolved oxygen to assess quality status and suitability for use. Information on concentration of toxic and trace metals in the delta is scarce partly because of the perception that the delta is pristine but also because there are no large industrial and agricultural productions in the river basin to generate such pollutants. However, deterioration of

O. Mogobe, omogobe@ub.ac.bw | ${ }^{1}$ Okavango Research Institute, University of Botswana, P/Bag 285, Maun, Botswana. ${ }^{2}$ Botswana International University of Science and Technology, P/Bag 16, Palapye, Botswana. 
surface water quality through both natural and anthropogenic processes has been reported worldwide by many scientists [6-8], and not many ecosystems remain unchanged. Among pollutants of concern in surface waters are trace metals, released into water bodies from erosion and mineral weathering, atmospheric deposition, storm water run-off, domestic waste, agricultural and industrial waste $[6,7,9]$. These pollutants may have devastating effects on ecological balance, diversity of aquatic organisms as well as on human health. Some trace metals exert toxicity in organisms by targeting cellular organelles and disrupting biochemical and physiological functions of aquatic animals and plants. The effects are widespread and may include skeletal deformities in fish and other organisms, impairment and inhibition of plant growth and decreased hatching rate [10]. In drinking water, if trace metals such as cadmium, lead, chromium and nickel are ingested by people in high concentrations, they may have negative health impact such as cardiovascular and skeletal disorders, reproductive problems, cancers, neurotoxicity and DNA damage [11].

Some communities living along the Okavango River system use river water as a drinking source without any treatment [3], but information on levels of trace metals in the river is very limited. Health risk assessment is an essential tool that gives information on the extent of contamination, exposure of people to contaminants and associated health risks. The objective of this study was to quantify the concentrations of selected trace metals, investigate their distribution in the Okavango Panhandle and evaluate health risks to adults and children who are ingesting untreated river water in the Okavango Panhandle. This research was part of a larger project monitoring the water quality of the Okavango Delta over a period of 3 years, from 2014 to 2017. The sampling sites were selected to represent the entire Okavango Delta, but the middle part was not included in the study because it is mainly permanent marshy swamps not accessible by road. The results presented in this paper are the first water quality data on trace metals, generated continuously over a longer period (more than 1 year) and the first human health risk assessment from exposure to trace metals through drinking river water in the Okavango Delta. This study will attempt to give a comprehensive picture on the spatial/temporal changes and health risks associated with trace metals in the upper delta.

\section{Materials and methods}

\subsection{Study area}

Figure 1 shows the water quality monitoring sites of the Okavango Panhandle as well as the lower Okavango Delta.
This paper will only look at the Okavango Panhandle sites comprised of Mohembo, Sepopa, Crescent Island, Etsatsa and Guma. Ngami west region occupies a space in the North-West District of Botswana and is a home to about 59,421 inhabitants [12] scattered around in several villages, some along the Okavango River shown (Fig. 2). The Okavango River, the fourth longest river in southern Africa, has its headwaters in the Angolan highlands (annual average rainfall $\sim 900 \mathrm{~mm}$ ) and traverses through three countries; Angola, Namibia and Botswana. It is one of the two perennial rivers in Botswana and is part of the famous Okavango Delta. The geography of the area is mainly flat arid land with deep Kalahari Desert sands. The mean annual rainfall in the delta is about $450 \mathrm{~mm}$, and highest temperatures in summer can go beyond $40^{\circ} \mathrm{C}$. Annual flow into the delta is about 11,000 million $\mathrm{m}^{3}$ plus 5000 million $\mathrm{m}^{3}$ from local rainfall. Although the government is working hard to supply improved drinking water to the entire population of Botswana, in villages of Ngamiland West sub-district (Fig. 2), about $8.7 \%$ of the households still use river water as a direct drinking source, without any treatment [13]. However, people are now engaging in commercial agriculture, and forests are being cleared for settlements in the Angolan side of the basin and these activities may have impact on water quality. Knowledge on the water quality of the Okavango River is therefore very important because the quality can affect human, wildlife and ecosystem health.

\subsection{Sampling}

A total of 492 surface water samples were collected from the Upper Okavango River at five sampling sites: Mohembo, Sepopa, Etsatsa, Crescent Island and Guma (Fig. 1). Sampling was conducted monthly for the entire sampling period to cover periods of high and low floods. Each sample was triplicated, using water grab sampling method [14], between July 2014 and July 2017. Samples were collected just below the water surface with sampling bottles. These $500 \mathrm{ml}$ polyethylene bottles were prewashed with distilled water, then with $10 \%$ nitric acid and finally rinsed with milli-Q water. Before collecting a sample, the bottle was rinsed with river water first. Immediately after collection, samples were acidified with $1.5 \mathrm{ml}$ of $65 \%$ nitric acid for preservation, closed and transported to the Okavango Research Institute Environmental laboratory in cooler boxes for metal analysis.

\subsection{Analytical procedures}

These river water samples collected were not filtered in order to quantify trace elements in water 'as drunk' and also to avoid any potential filtration effects which have 


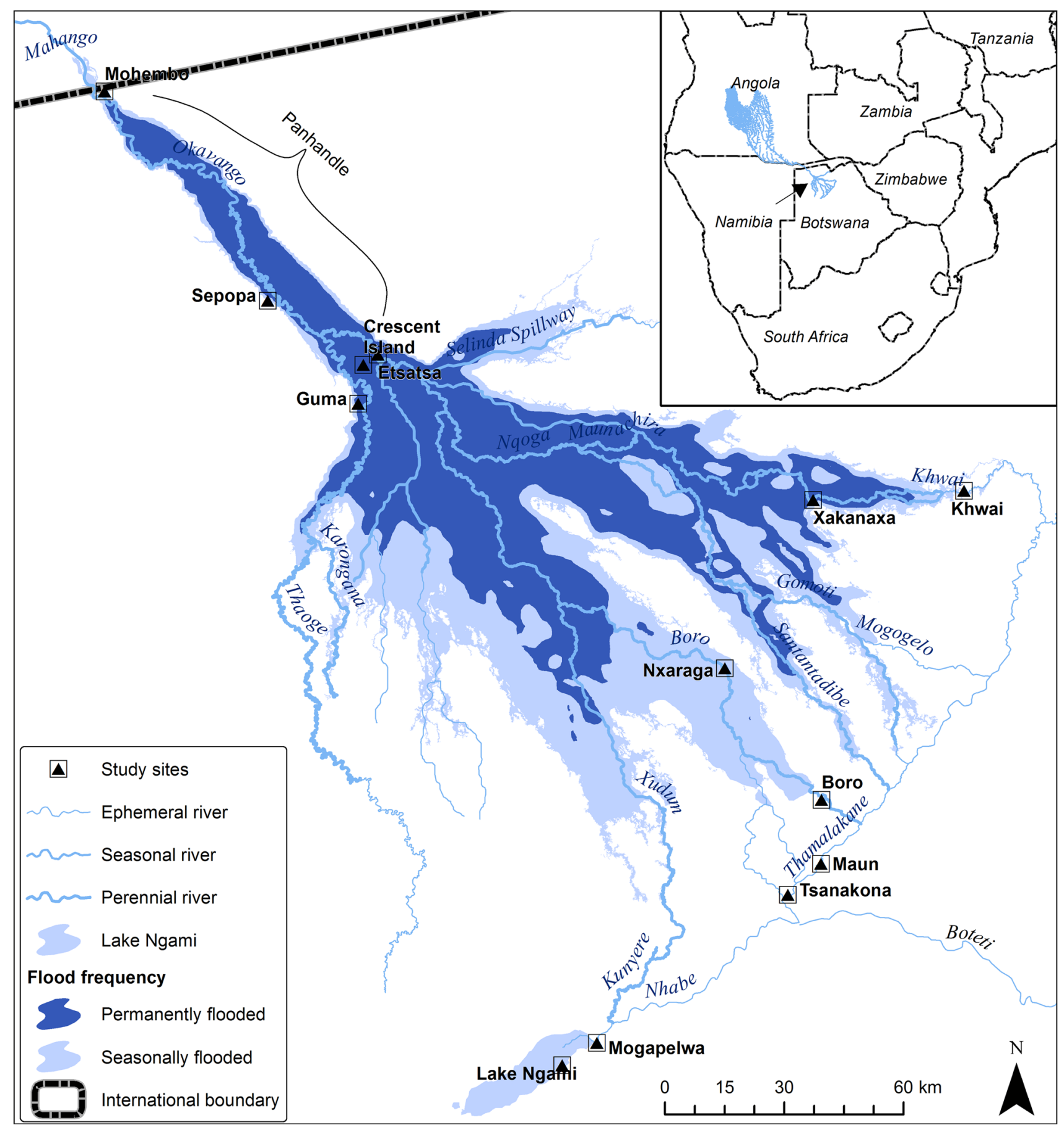

Fig. 1 Sampling sites of the Okavango Delta for the entire project, the Panhandle and Lower delta

been articulated on the literature by Hall and Horowitz $[15,16]$. Turbidity of the river water ranged between 1 and 19 NTU, measured on site during sampling. The samples were left to stand for at least 1 week to allow suspended particles to settle to the bottom before analysis. Total concentrations of 10 trace metals $(\mathrm{Fe}, \mathrm{Cu}, \mathrm{Mn}, \mathrm{Zn}, \mathrm{Cr}, \mathrm{Pb}, \mathrm{Ni}, \mathrm{Co}$, $\mathrm{Cd}$, and $\mathrm{V}$ ) were measured from unfiltered samples with
ICP-OES directly using US EPA method 200.7 [17]. The optimised operating parameters for ICP-OES (Perkin Elmer, Optima 2100DV) were plasma torch positioned at axial view, peristaltic pump flow rate set at $1.5 \mathrm{ml} / \mathrm{min}$ and the nebuliser gas set at $0.8 \mathrm{l} / \mathrm{min}$. The plasma gas was argon at $15 \mathrm{l} / \mathrm{min}$, and the auxiliary gas was nitrogen set at $0.2 \mathrm{l} /$ $\mathrm{min}$. Metals were analysed at recommended wavelengths 


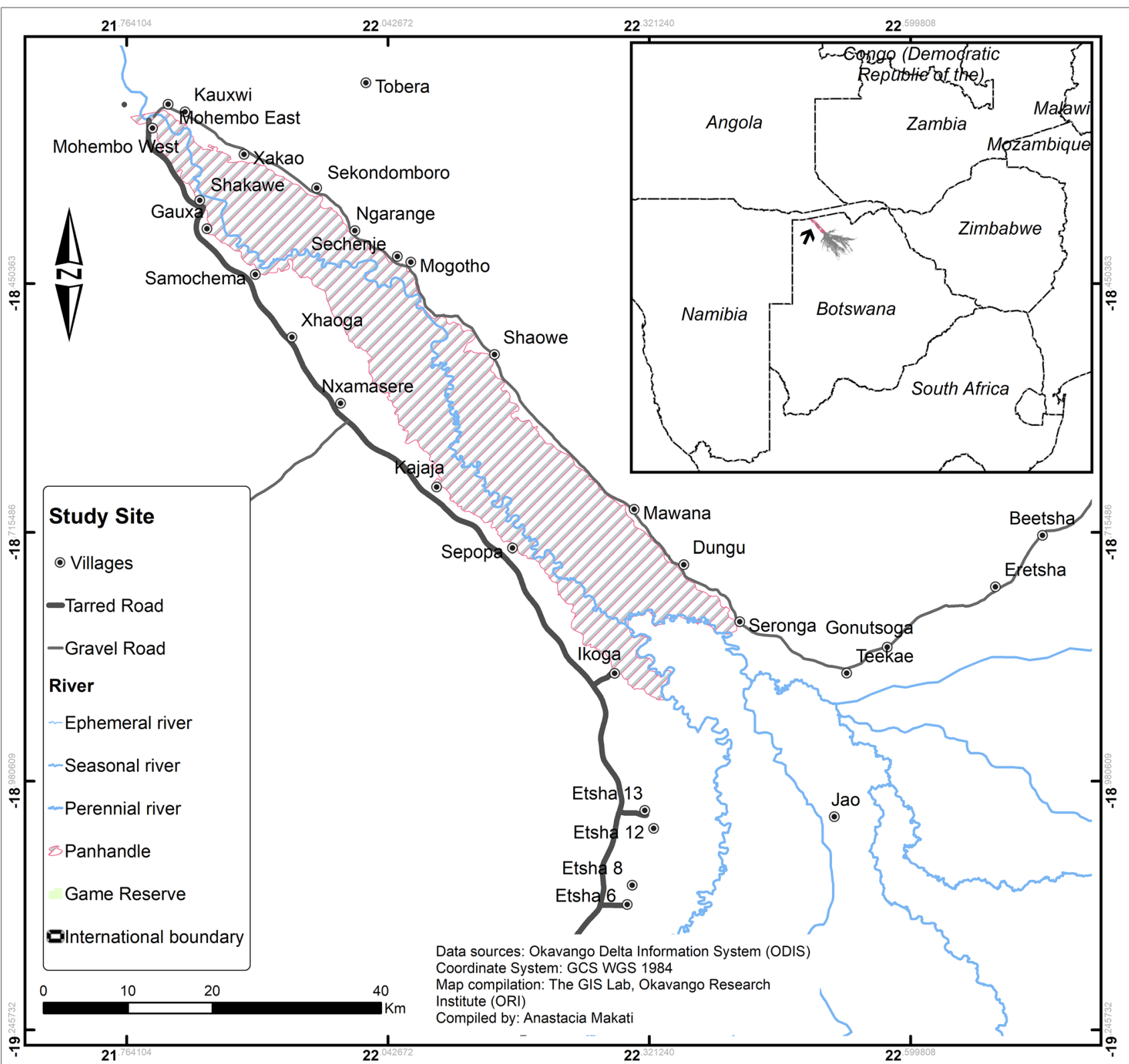

Fig. 2 Villages along the Okavango Panhandle using Okavango River as a drinking source

for ICP-OES, and detection limits for the trace metals are given on Table 1. Multi-element calibration standards were prepared from single element $100 \mathrm{ppm}$ stock solutions which were in turn prepared from single element 1000 ppm standard solutions. A 3-point calibration for each element was used for calculating the concentrations of these trace metals.

\subsection{Quality assurance}

All samples were analysed in triplicates, with two instrument blanks made up of $2 \%$ nitric acid for each batch.
In-house quality control samples (river water, borehole water and synthetic water), obtained from South African Bureau of Standards (SABS 2015-Group 1) and Botswana Bureau of Standards (NQCSES-Group1) previously used for proficiency testing program in the Okavango Research Institute laboratory, were analysed with each batch and the recovery rates for metal concentrations ranged between 75 and $120 \%$. Milli-Q water was used for rinsing glassware and preparing reagents. All chemicals used were of analytical grade. 
Table 1 List of wavelengths used and detection limits for ICPOES - analysis of river water from the Upper Okavango Delta

\begin{tabular}{lll}
\hline Analyte & Wavelength $(\mathrm{nm})$ & $\begin{array}{l}\text { Detection } \\
\text { limits }(\mu \mathrm{g} / \mathrm{l})\end{array}$ \\
\hline $\mathrm{Fe}$ & 238.204 & 0.2 \\
$\mathrm{Cu}$ & 324.752 & 0.9 \\
$\mathrm{Mn}$ & 257.610 & 0.03 \\
$\mathrm{Zn}$ & 213.857 & 0.2 \\
$\mathrm{Cr}$ & 267.716 & 0.25 \\
$\mathrm{~Pb}$ & 220.353 & 1.4 \\
$\mathrm{Ni}$ & 221.648 & 0.4 \\
$\mathrm{Co}$ & 228.616 & 0.25 \\
$\mathrm{Cd}$ & 228.802 & 0.07 \\
$\mathrm{~V}$ & 290.880 & 0.15 \\
\hline
\end{tabular}

\subsection{Data analysis}

Statistical software IBM SPSS version 24 was used for data analysis. Descriptive statistics was performed to obtain means, concentration ranges and standard deviation of the data. One way ANOVA at $p \leq 0.05$ was used to determine if there were significant differences in metal concentrations between sampling locations, followed by Tukey's HSD post hoc test for multiple comparisons of mean concentrations among sampling locations. To determine if there were any significant differences in metal concentrations between high and low floods, sampling locations were combined and then one way ANOVA by flood level performed on the data.

\subsection{Exposure to trace metals}

The most important entry pathway of heavy metals into the human body is through ingestion: drinking of water and food consumption $[18,19]$. In this study, only water ingestion was used to estimate the daily intake of metals by adults and children living in villages where river water is the main drinking source. The mean concentrations used for daily metal intake were averages calculated by SPSS descriptive analysis for the entire study period, combining all study areas. Using guidelines provided by US EPA [20], the exposure to metal contaminants was calculated according to a modified formula used by Muhammed and Batayneh [19, 21] where,

$\mathrm{CDI}=\mathrm{C} \cdot \frac{\mathrm{DI}}{\mathrm{BW}}$

$\mathrm{CDI}$ is the chronic daily intake of the contaminant $(\mathrm{mg} /$ $\mathrm{kg}$ - day), $C$ is the concentration of the trace metal in question $(\mathrm{mg} / \mathrm{l}), \mathrm{Dl}$ is the average daily intake of water in litres and BW is the average body weight of an adult or child in kilograms. In this study, we used references used by the US Environmental Protection Agency [22] where daily water intake for children between 6 and 12 months is $1.18 \mathrm{I}$, 6-11 years is $1.55 \mathrm{I}$ and for adults, it is $2.04 \mathrm{I}$. The average adult body weight used for adults was $60 \mathrm{~kg}$; children between 6 and 12 months were $9.4 \mathrm{~kg}$, and for 6-11 year olds the weight was $36 \mathrm{~kg}$.

\subsection{Target hazard quotient (THQ)}

The non-cancer risk associated with chronic intake of the trace elements under study through drinking the Okavango River water was also evaluated by hazard quotient, THQ. The hazard quotient is used to evaluate the risk and is calculated according to US Environmental Protection Agency [23] expression;

$\mathrm{HQ}=\frac{\mathrm{CDI}}{\mathrm{RfD}}$

where $\mathrm{HQ}$ is the hazard quotient and RfD is the reference dose of the metal or the tolerable daily intake. The population exposed to the contaminant is said to be safe if the $\mathrm{HQ}$ is $\leq 1$ [23].

\section{Results and discussion}

\subsection{Distribution of trace metals}

These results represent total metal concentrations which were measured on unfiltered water samples. The concentrations of 10 trace metals investigated in surface water of the Okavango Panhandle, at five sampling sites are displayed in Table 2, showing spatial and temporal variations. Concentration of metals in aquatic systems is influenced by environmental conditions such as redox potential, $\mathrm{pH}$, ion activity, river flow rate and also the geology of the catchment as articulated by Nordstrom [24]. It is therefore important when studying distribution of metals in river systems to also measure these parameters that act as drivers of concentration variability. The $\mathrm{pH}, \mathrm{EC}, \mathrm{DO}$ and other physico-chemical parameters of the Panhandle waters were measured by the authors at the same time, parallel to this study and the data published in 2018 [25]. From that publication, Mogobe et al., showed that Mohembo recorded a pH range of 5.6-7.2; Sepopa 5.9-7.0; Etsatsa 5.2-7.3; Crescent 5.7-7.5 and Guma 5.8-7.4 [25]. These results show a variation in $\mathrm{pH}$ between acidic to slightly above neutral, conditions that may have contributed, together with the watershed geology and changing redox conditions, to variations in trace metal concentrations at different study sites and hydrological seasons of the Okavango Panhandle. 


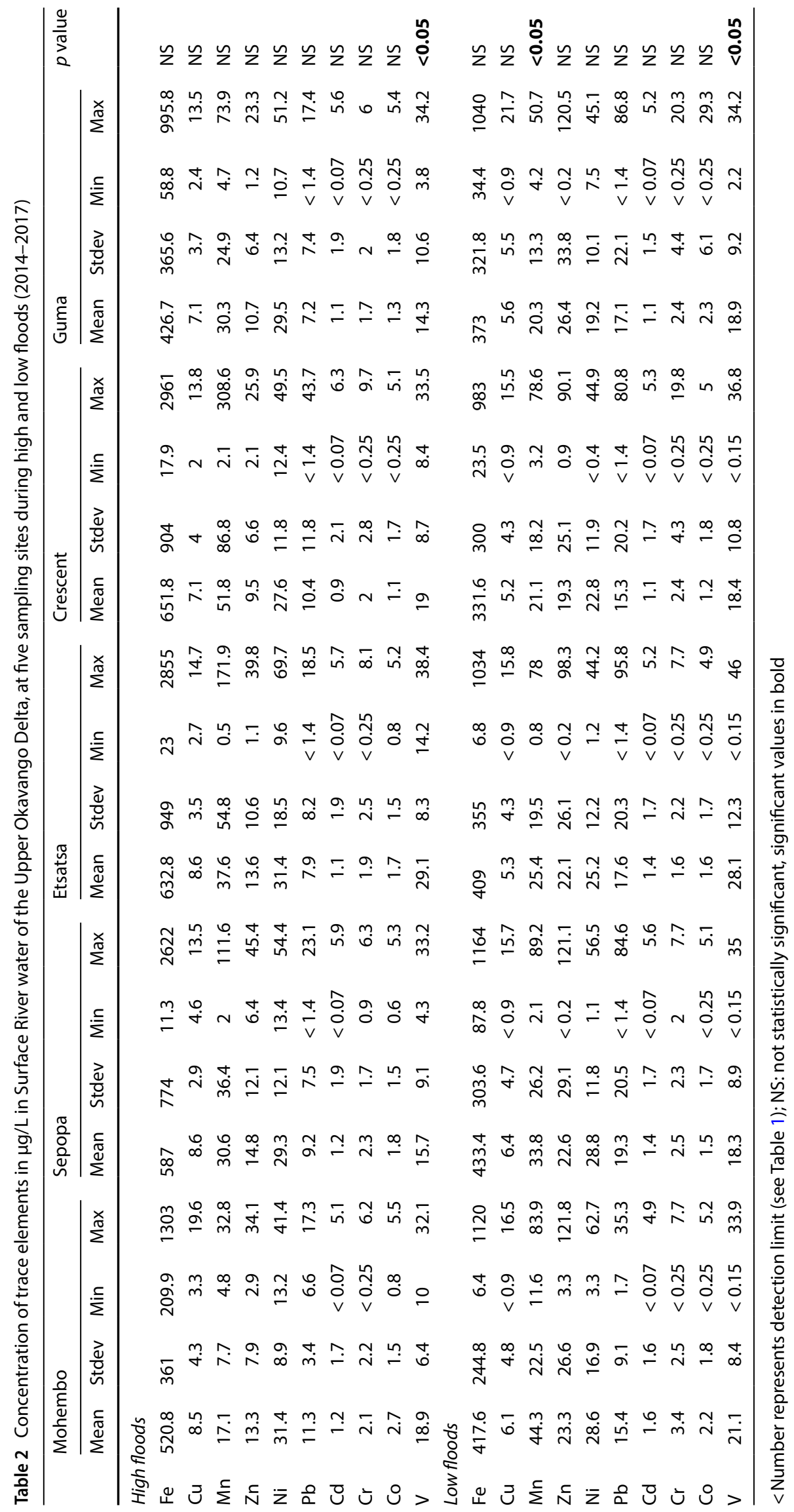




\subsubsection{Spatial distribution}

All trace metals investigated were present at all study sites at small varying concentrations. Generally the mean concentration of metals in the Panhandle occurred in the order $\mathrm{Fe}>\mathrm{Mn}>\mathrm{Ni}>\mathrm{V}>\mathrm{Zn}>\mathrm{Pb}>\mathrm{Cd}>\mathrm{Cu}>\mathrm{Cr}>\mathrm{Co}$. These results depicting metal abundances in the Okavango River compare closely to the relative abundance of elements in the earth's crust, published by Clarke [26], where Fe and $\mathrm{Mn}$ are the most abundant. The occurrence of this wide range of trace elements in the Okavango River, although present at relatively low concentrations, may indicate weathering and erosion of mafic-ultramafic rocks in the catchment area since mafic and ultramafic rocks have this wide range of trace metal composition $[24,26]$. This proposition that the source rock in the Angolan catchment is made up of mafic and ultramafic rock types is supported by Huntsman-Mapila's findings that sediments in the Okavango River have their origin from ultramafic and mafic rock types [27]. However, other rock types are probably present in the catchment area. The studied elements had negligible variable concentrations between study sites, with no detectable trend except for Fe and $\mathrm{Mn}$ which showed some increasing concentration downstream during high floods. Fe and Mn have similar hydrochemistry, and their concentrations are driven mainly by redox potentials. A study in Sweden by Ekstrom et al., observed that Fe increases in concentration when conditions become anoxic due to microbial-mediated reduction in $\mathrm{Fe}$ (III) to the more soluble Fe(II) [28]. A parallel study to the current study in the Okavango Panhandle conducted by the authors observed a general decreasing mean concentration of dissolved oxygen downstream during high floods [25]. This phenomenon creates reducing conditions, solubilizing ferro-manganese oxy-hydroxides from sediments and increasing concentrations in the water column. This explains the increasing $\mathrm{Fe}$ and $\mathrm{Mn}$ concentrations downstream during the period of high floods. Fe shows distinctively higher concentrations at all sampling sites compared to other elements, more than three orders of magnitude higher, ranging from 6.4 to a maximum of $2961 \mu \mathrm{g} / \mathrm{l}$. Fe is ubiquitous in the earth's crust and abundant in some rocks such as hematite, which may be responsible for the high concentrations but also the reductive conditions that prevail in wetlands favour increased concentration of Fe. The mean concentrations of the studied metals, during low floods, did not show any significant spatial variability except for $\mathrm{Mn}$ and $\mathrm{V}(p<0.05)$ as depicted in Table 2. Tukey's HSD post hoc analysis revealed that the significant differences at low floods were due to higher concentration of $\mathrm{Mn}$ at Mohembo $(44.3 \mu \mathrm{g} / \mathrm{l})$ compared to Etsatsa $(25.4 \mu \mathrm{g} / \mathrm{l})$, Crescent $(21.1 \mu / \mathrm{l})$ and Guma $(14.3 \mu \mathrm{g} / \mathrm{l})$. Actually, the concentration of $\mathrm{Mn}$ was decreasing downstream at low floods. In the absence of large industrial activities and the current 'pristine' nature of the delta, as demonstrated by some past research $[2,4,5]$, atmospheric deposition and geogenic erosion processes in the catchment are likely to be important contributors to sources of metals in the Panhandle. Peak concentrations were observed from the lower segment of the Panhandle; for example, $60 \%$ of the trace metals had their peak values at Crescent Island ( $\mathrm{Fe}, \mathrm{Mn}$ and $\mathrm{Cd}$ ) and Etsatsa ( $\mathrm{Ni}, \mathrm{Pb}$ and $\mathrm{V})$. This is probably due to reduced river flow at these sites resulting in metal build-up but also due to the hydrogeochemistry of individual metals.

\subsubsection{Seasonal distribution}

The low floods occur when the floods start to recede during the month of July to December, a summer time when evaporation rate is also at its highest. Table 2 shows that at times during the study period, the maximum concentrations of Fe at $2961 \mu \mathrm{g} / \mathrm{l}, \mathrm{Pb}$ at $95.8 \mu \mathrm{g} / \mathrm{l}$ and $\mathrm{Cd}$ at $6.3 \mu \mathrm{g} / \mathrm{l}$ were above the WHO drinking water guidelines $(2000,10$, $3 \mu \mathrm{g} / \mathrm{l}$, respectively) with a potential of inducing metal toxicity to the riparian communities who drink this water and also affecting aquatic organisms. It was observed that $\mathrm{Fe}, \mathrm{Mn}, \mathrm{Cd}$ and $\mathrm{Ni}$ had their highest concentrations during high floods, whereas the remaining six metals $(\mathrm{Cu}, \mathrm{Zn}, \mathrm{Pb}$, $\mathrm{Cr}, \mathrm{Co}$ and $\mathrm{V}$ ) recorded the highest concentrations at low floods. Trace metals behave differently in aquatic environments, reflecting their individual geochemistry. The concentration peaks of the four metals at high floods reflect that unique hydrogeochemistry but also may imply that high volume river water bring in more metal ions resulting from storm waters, weathering processes in the catchment area and also contribution from sediments due to changing redox conditions. The observed peak concentrations at low floods may be attributed to high evaporative concentration during this period, reflecting similar observation by Li et al. [7] in the Upper Han River, China. On the other hand, dilution effects at high floods resulted in some metals having lower concentrations at high discharge, again in agreement with observations by Li et al. [7]. Statistically, there was no significant difference $(p>0.05)$ in metal concentration between hydrological seasons (high and low floods).

\subsection{Comparison of trace metal concentrations with past studies and international guidelines}

This section compares the concentrations of trace metals in the Okavango Panhandle to world values, past research and international guidelines for aquatic and drinking water criteria. The results from this study show that mean concentrations of $\mathrm{Cu}, \mathrm{Mn}, \mathrm{Zn}, \mathrm{Ni}, \mathrm{Pb}$ and $\mathrm{Co}$ 
are all higher than the world average values for riverine systems, (Table 3). However, mean Fe concentrations are lower to world average values at both high and low flood levels. A past study by Sawula and others [29] conducted on total trace metals in the Okavango Delta obtained comparable results on some metals, and others were lower compared to the current study. Interestingly, the highest dissolved concentrations measured at Mohembo by Masamba and Muzila [30] were much higher than total concentrations found on this study. This could be due to different analytical techniques used in the two studies. It must be noted that the obtained total concentrations were compared with dissolved concentrations from past studies because measurements were conducted in the same river system, and there is not much data available on the literature regarding trace metals in the Okavango. The results (Table 3) also show that total concentrations of $\mathrm{Ni}$ in the 1992 study by Sawula et al. [29] are comparable to total concentrations obtained in the present study. However, $\mathrm{Cu}, \mathrm{Zn}, \mathrm{Pb}, \mathrm{Cd}$ and $\mathrm{Co}$ concentrations from Sawula study were much higher than in the present study. This could indicate the efficiency of wetland processes in removing metals from the water column. In terms of international guidelines, this study found that the mean concentrations of $\mathrm{Fe}, \mathrm{Cu}, \mathrm{Mn}, \mathrm{Zn}, \mathrm{Ni}, \mathrm{Cd}, \mathrm{Cr}$ and $\mathrm{Co}$ were all within the $\mathrm{WHO}$ threshold for drinking water, (Table 3 ). Pb with concentrations of $0.009 \mathrm{mg} / \mathrm{l}$ at high floods and $0.017 \mathrm{mg} / \mathrm{l}$ at low floods was equal to and a bit higher than the WHO drinking water threshold of $0.01 \mathrm{mg} / \mathrm{l}$, respectively.

This may become a concern because $\mathrm{Pb}$ is very toxic and has known negative human health effects [31], and concentrations may accumulate in aquatic organisms and transferred to humans through the food web. Concentrations of $\mathrm{Cd}$ are too close to the threshold, but chronic exposure of people to $\mathrm{Cd}$ may lead to renal and bone alterations [32, 33], whereas $\mathrm{Pb}$ may result in reproductive and neuro-developmental abnormalities. The presence of $\mathrm{Cd}$ in water bodies may be attributed to release from sediments as suggested by Yin et al. [34] and also from fertilisers and pesticides because agricultural activities have increased in recent years in the Okavango River basin [35]. Concentration of $\mathrm{Pb}$ at high and low floods $(0.009$ and $0.017 \mathrm{mg} / \mathrm{l}$, respectively) was higher than the EPA chronic threshold $(0.003 \mathrm{mg} / \mathrm{l})$ for aquatic life (Table 3). Also, concentration of $\mathrm{Cd}$, which was $0.001 \mathrm{mg} / \mathrm{l}$ at both flood levels, was too close to the limit for acute toxicity and equal to the limit for chronic effects on aquatic life, (Table 3). The study on trace metals in the Okavango conducted by Sawula [36] reported that there was no evidence then, that $\mathrm{Pb}, \mathrm{Cd}$ and $\mathrm{Cu}$ were present in concentrations harmful to aquatic life. Some metal concentrations are too close to threshold values $(\mathrm{Cd}, \mathrm{Pb})$ and may become potential threats to human and aquatic life in the Okavango Panhandle in future. A study by Galvin [32] reported that sources of $\mathrm{Pb}$ in water bodies may be due to residual pesticides or even leaded fuel used in boat cruises; this may be true as well for this river basin as it houses these activities. These findings may be used in further developing conservation strategies to enhance and support sustainable use of the river basin.

\subsection{Human health risk}

Most villages along the Okavango Delta (Fig. 2) use river water directly for drinking and other household activities without any treatment $[3,13]$. Mean concentrations of trace metals in the river water indicate the presence and amounts of contaminants but do not quantify the actual risks posed by these metals to human health. Table 4 shows the mean concentrations of metals calculated for the combined sampling locations during the entire study period. Table 4 also shows the chronic daily intakes and hazard quotient of trace metals calculated from Eqs. 1 and 2 , which are given on methodology section of this study. These parameters quantify the human exposure levels and health risks associated with trace metals in the river water.

The risk concern is said to exist when the $\mathrm{HQ}$ is above unity according to several authors [7, 34, 42]. In this study, children tend to have higher exposure risks to metals and children of 6-12 months have the highest daily metal intake of trace metals compared to the 6-11 year olds and adults (Table 4). This may result in accumulation of trace metals in body tissues into adulthood. The highest hazard quotients obtained in this study were from chronic exposure to $\mathrm{Co}$ and $\mathrm{Pb}$ with $\mathrm{HQ}$ of 1 and 0.56 , respectively, for children aged 6-12 months (Table 4). Following $\mathrm{Pb}$ in hazard value was $V$ with 0.33 , followed by $\mathrm{Cd}$ and Fe with $0.20 \mathrm{HQ}$ value. Although the $\mathrm{HQ}$ values for all metals in this assessment were not more than 1 , it must be noted that 6-12 months children are a very sensitive group to health risks and hazard values of 1 and 0.56 may still manifest into some form of toxicity effects. Cobalt is an essential element as a constituent of vitamin $B_{12}$ but can also have toxicity effects such as allergic dermatitis, cardiomyopathy and some types of cancers [43] when occurring in high concentrations. The Co hazard value of 1 for $6-12$ months children must be treated as a cautionary level for possible toxicity to this age group in the Okavango Panhandle. $\mathrm{Pb}$ is of particular concern because it has a long half-life in the body and a profound neurotoxicity effects on developing brains than on mature brains [44]. Studies on effects of $\mathrm{Pb}$ in children have shown diminished intelligence, lower intelligence quotient $(\mathrm{IQ})$, impaired neurobehavioral development and other effects [31]. The HQ is less than unity again, but given the adverse effect on children, these concentrations should be treated as warning levels for potential toxic effects. Other trace metals in this study 
Table 3 Present values compared with past studies and international guidelines for aquatic and drinking water criteria

\begin{tabular}{|c|c|c|c|c|c|c|c|c|c|c|}
\hline $\begin{array}{l}\text { Present \& past } \\
\text { studies and } \\
\text { international } \\
\text { water quality } \\
\text { guidelines }\end{array}$ & $\mathrm{Fe}$ & $\mathrm{Cu}$ & $\mathrm{Mn}$ & $\mathrm{Zn}$ & $\mathrm{Ni}$ & $\mathrm{Pb}$ & $\mathrm{Cd}$ & $\mathrm{Cr}$ & Co & V \\
\hline $\begin{array}{l}\text { World average } \\
\text { values for } \\
\text { riverine sys- } \\
\text { tems [37] }\end{array}$ & 0.67 & 0.005 & 0.005 & 0.01 & 0.0003 & 0.0003 & - & - & 0.0002 & - \\
\hline $\begin{array}{l}\text { Past studies } \\
\text { OD, Boro } \\
\text { [29] }\end{array}$ & - & 0.033 & - & 0.036 & 0.026 & 0.067 & 0.039 & - & 0.066 & - \\
\hline $\begin{array}{l}\text { Past studies } \\
\text { OD, highest } \\
\text { values at } \\
\text { Mohembo } \\
\text { [30] }\end{array}$ & 0.60 & 0.028 & 0.044 & 0.101 & 0.052 & 0.280 & - & - & 0.053 & - \\
\hline $\begin{array}{l}\text { This study- } \\
\text { average for } \\
\text { Panhandle } \\
\text { (high floods) }\end{array}$ & 0.563 & 0.008 & 0.034 & 0.012 & 0.030 & 0.009 & 0.001 & 0.002 & 0.002 & 0.019 \\
\hline $\begin{array}{l}\text { This study- } \\
\text { average for } \\
\text { Panhandle } \\
\text { (low floods) }\end{array}$ & 0.392 & 0.006 & 0.029 & 0.023 & 0.025 & 0.017 & 0.001 & 0.003 & 0.002 & 0.021 \\
\hline $\begin{array}{l}\text { Freshwater } \\
\text { quality } \\
\text { criteria for } \\
\text { aquatic } \\
\text { life acute } \\
\text { effects (EPA) } \\
\text { [38] }\end{array}$ & - & - & - & 0.120 & 0.470 & 0.065 & 0.002 & 0.016 & - & - \\
\hline $\begin{array}{l}\text { Freshwater } \\
\text { quality } \\
\text { criteria for } \\
\text { aquatic } \\
\text { life chronic } \\
\text { effects (EPA) } \\
\text { [38] }\end{array}$ & 1.0 & - & - & 0.120 & 0.052 & 0.003 & 0.001 & 0.011 & - & - \\
\hline $\begin{array}{l}\text { Drinking } \\
\text { water qual- } \\
\text { ity guide- } \\
\text { lines [11] }\end{array}$ & 2.0 & 2.0 & 0.4 & 3 & 0.07 & 0.01 & 0.003 & 0.05 & 0.5 & - \\
\hline
\end{tabular}

All metal concentrations in mg/l, OD for Okavango Delta, bolded values represent higher than the international guideline

have negligible health risks. Most people in rural villages of developing countries, including the Okavango Panhandle, do not have access to improved drinking water and therefore boil water for babies to make it safe for drinking. Unfortunately, this method of treatment may kill pathogenic bacteria but does not get rid of toxic metals in the water. Cheap technologies for removing contaminants in drinking water need to be developed, especially designed to be used by remote rural residents.

\section{Conclusions}

The study revealed that all the 10 trace metals investigated ( $\mathrm{Fe}, \mathrm{Cu}, \mathrm{Mn}, \mathrm{Zn}, \mathrm{Ni}, \mathrm{Pb}, \mathrm{Cd}, \mathrm{Cr}, \mathrm{Co} \& \mathrm{~V}$ ) were present in the Okavango Panhandle, ranging from concentrations below detection limit to the highest $(\mathrm{Fe}$ ) concentration at Crescent Island. The abundance of these metals in the river water followed the order, $\mathrm{Fe}>\mathrm{Mn}>\mathrm{Ni}>\mathrm{V}>\mathrm{Zn}>\mathrm{Pb}>\mathrm{Cd}$ $>\mathrm{Cu}>\mathrm{Cr}>\mathrm{Co}$, closely reflecting relative abundances of metals in some igneous and sedimentary rocks, published by US Geological Survey [26]. The wide range of metals 
Table 4 Chronic daily intake and hazard quotient of trace metals for targeted population groups in the Okavango Delta Panhandle

\begin{tabular}{|c|c|c|c|c|c|c|c|c|}
\hline & \multirow{2}{*}{$\begin{array}{l}\text { Mean concentra- } \\
\text { tions (mg/l) }\end{array}$} & \multicolumn{3}{|c|}{ CDI for targeted group } & \multirow[t]{2}{*}{ RfD } & \multicolumn{3}{|c|}{$\mathrm{HQ}$ for targeted group } \\
\hline & & $\begin{array}{l}\text { Children } \\
\text { (6-12 months) }\end{array}$ & $\begin{array}{l}\text { Children } \\
\text { (6-11 years) }\end{array}$ & Adults & & $\begin{array}{l}\text { Children } \\
\text { (6-12 months) }\end{array}$ & $\begin{array}{l}\text { Children } \\
\text { (6-11 years) }\end{array}$ & Adults \\
\hline $\mathrm{Fe}$ & $0.457 \pm 0.499$ & 0.057 & 0.019 & 0.016 & $0.70^{\mathrm{b}}$ & 0.08 & 0.027 & 0.022 \\
\hline $\mathrm{Cu}$ & $0.007 \pm 0.004$ & 0.0009 & 0.0003 & 0.0002 & $0.04^{b}$ & 0.02 & 0.01 & 0.005 \\
\hline $\mathrm{Mn}$ & $0.031 \pm 0.035$ & 0.004 & 0.001 & 0.001 & $0.14^{\mathrm{a}}$ & 0.03 & 0.01 & 0.007 \\
\hline $\mathrm{Zn}$ & $0.019 \pm 0.023$ & 0.002 & 0.0008 & 0.0006 & $0.30^{\mathrm{a}}$ & 0.01 & 0.003 & 0.002 \\
\hline $\mathrm{Ni}$ & $0.027 \pm 0.013$ & 0.003 & 0.001 & 0.0009 & $0.02^{\mathrm{a}}$ & 0.15 & 0.05 & 0.05 \\
\hline $\mathrm{Pb}$ & $0.014 \pm 0.015$ & 0.002 & 0.0006 & 0.0005 & $0.0035^{c}$ & 0.56 & 0.17 & 0.14 \\
\hline $\mathrm{Cd}$ & $0.001 \pm 0.002$ & 0.0001 & 0.00004 & 0.00003 & $0.0005^{\mathrm{a}}$ & 0.20 & 0.08 & 0.06 \\
\hline $\mathrm{Cr}$ & $0.002 \pm 0.003$ & 0.0003 & 0.00008 & 0.00007 & $0.003^{\mathrm{a}}$ & 0.10 & 0.03 & 0.02 \\
\hline Co & $0.002 \pm 0.003$ & 0.0003 & 0.00008 & 0.00007 & $0.0003^{b}$ & 1.00 & 0.27 & 0.23 \\
\hline V & $0.020 \pm 0.010$ & 0.003 & 0.0009 & 0.0007 & $0.009^{a}$ & 0.33 & 0.10 & 0.08 \\
\hline
\end{tabular}

$\mathrm{CDI}$ is the chronic daily intake of metals in $\mathrm{mg} / \mathrm{kg}$-day, $\mathrm{HQ}$ is the hazard quotient, and $\mathrm{RfD}$ is the reference dose for each metal

aUS EPA IRIS [39]

bUS EPA RSL [40]

'JEFCA [41]

occurring in the Okavango waters suggest a source rock in the catchment area that has a wide composition of metals, probably mafic and ultramafic rock types. Although the mean trace metal concentrations seemed to differ between study sites and flood levels probably due to the geochemistry of individual metals, most of these variations were not statistically significant at $p \leq 0.05$, reflecting a relatively homogenous trace metal composition in the Panhandle. Risk assessment indicated that all metals investigated complied with the US EPA standard for freshwater aquatic life. Also, there were no human health risks from trace metals through drinking river water, but $\mathrm{Co}$ and $\mathrm{Pb}$ may pose some risks over time, especially to the vulnerable 6-12 months children. It is recommended that more studies on trace metals and other emerging contaminants be conducted, ecological and human health risks evaluated for the protection of the riparian population and sustainability of the ecosystem.

Acknowledgements Appreciation for assistance goes to all research field staff of the Okavango Research Institute Monitoring unit. Analytical laboratory work was conducted at the Okavango Research Institute Environmental Laboratory, and the maps were developed by the Okavango Research Institute's Geographical Information Systems laboratory. Special thanks go to Mr Wakongwa Toro for sample analysis and data entry. This project was supported under Southern African Science Service Centre for Climate Change and Adaptive Land Management (SASSCAL) program, funded by the Federal Republic of Germany.

\section{Compliance with ethical standards}

Conflict of interest Authors have no conflict of interest in this research paper.

\section{References}

1. Gleick PH, IWRA M (1996) Basic water requirements for human activities: meeting basic needs. Water Int 21:83-92

2. Mackay AW et al (2011) Spatial and seasonal variability in surface water chemistry in the Okavango Delta, Botswana: a multivariate approach. Wetlands 31:815-829

3. Mazhimavi D, Mmopelwa G (2006) Access to water in gazetted and ungazetted rural settlements in Ngamiland, Botswana. Phys Chem Earth 31:713-722

4. Mmualefe L, Torto N (2011) Water quality in the Okavango Delta. Water SA 37:411-418

5. West D, Van As J, Van As L (2015) Surface water quality in the Okavango Delta Panhandle, Botswana. Afr J Aquat Sci 40:359-372

6. Liu H, Li W (2011) Dissolved trace elements and heavy metals from the shallow lakes in the middle and lower reaches of the Yangtze River region, China. Environ Earth Sci 62:1503-1511

7. Li S, Zhang Q (2010) Risk assessment and seasonal variations of dissolved trace elements and heavy metals in the Upper Han River, China. J Hazard Mater 181:1051-1058

8. Nriangu J (1996) A history of global metal pollution. Science 272:223-224

9. Chowdhury S, Al-Attas O, Hussain T (2016) Heavy metals in drinking water: occurences, implications and future needs in developing countries. Sci Total Environ 569-570:476-488

10. Solomon F (2008) Impacts of metals on aquatic ecosystems and human health. Environment and communities. https:// digital.lib.washington.edu/researchworks/handle/1773/16440. Accessed 29 Sep 2019

11. WHO (2006) Guidelines for drinking water quality. World Health Organisation, Geneva

12. Central Statistics Office, Botswana (2011) Population of towns, villages and associated localities. Statistics Botswana, Gaborone

13. Central Statistics Office, Botswana (2011) Water statistics. Statistics Botswana, Gaborone

14. U.S.EPA (1996) Method 1669—sampling ambient water for trace metals at EPA, water quality criteria levels. U.S.EPA, Washington, DC 
15. Hall GE et al (1996) The effect of using 0.45 micron filter membranes on dissolved element concentration in natural waters. Appl Geochem 11:243-249

16. Horowitz AJ, Elrick KA, Colberg MR (1992) The effect of membrane filtration artifacts on dissolved trace metals concentrations. Water Res 26:753-763

17. U.S.EPA (1994) Method 200.7: determination of metals and trace elements in water and wastes by inductively coupled plasmaatomic emission spectrometry. In: Martin TD, Martin ER (eds). U.S. Environmental Protection Agency, Cincinnati

18. Kavcar P, Sofuoglu A, Sofuoglu SC (2009) A health risk assessment for exposure to trace metals via drinking water ingestion pathway. Int J Hyg Environ Health 212:216-227

19. Muhammed S, Shah M, Khan S (2011) Health risk assessment of heavy metals and their source apportionment in drinking water of Kohistan region, northern Pakistan. Microchem J 98:334-343

20. U.S.EPA (1992) Guidelines for exposure assessment. U.S. Environmental Protection Agency, Washington, DC

21. Batayneh A (2012) Toxic (aluminium, beryllium, borob, chromium and zinc) in groundwater: health risk assessment. Int J Environ Sci Technol 9:153-162

22. U.S.EPA (2011) Exposure factors handbook 2011 edition. U.S. Environmental Protection Agency, Washington

23. U.S.EPA (2005) Human health risk assessement protocol for hazardous waste combustion facilities. U.S. Environmental Protection Agency, Washington

24. Nordstrom DK (2011) Hydrogeochemical processes governing the origin, transport and fate of major and trace elements from mine wastes and minirelised rock to surface waters. Appl Geochem 26:1777-1791

25. Mogobe $O$ et al (2018) Monitoring water quality of the Upper Okavango Delta. In: Revermann R et al (eds) Climate change and adaptive land management in southern Africa-assessments, changes, challenges and solutions. Klaus Hess, Gottingen, pp 106-111

26. Clarke FW (1924) The data of geochemistry. United States Geological Survey, Washington, DC

27. Huntsman-Mapila P et al (2005) Cryptic indicators of provenance from the geochemistry of the Okavango Delta sediments, Botswana. Sed Geol 174:123-148

28. Ekstrom SM et al (2016) Increasing concentrations of iron in surface waters as a consequence of reducing conditions in the catcment area. J Geophys Res Biogeosci 121:479-493

29. Sawula $G$ et al (1992) Notes on trace metals in the Boro River, Okavango Delta. Botsw Notes Rec 24:135-149

30. Masamba WRL, Muzila A (2005) Spatial and seasonal variation of major cation and selected trace metals ion concentration in the
Okavango-Muanachira-Khwai Channels of the Okavango Delta. Botsw Notes Rec 37:218-226

31. Tchounwou PB et al (2012) Heavy metal toxicity and the environment. Exp Suppl 101:133-164

32. Galvin RM (1996) Occurence of metals in waters: an overview. Water SA 22:7-18

33. Calabrese EJ, Canada AT, Sacco C (1985) Trace elements and public health. Annu Rev Public Health 6:131-146

34. Yin $S$ et al (2015) Heavy metal pollution in the surface water of the Yangtze estuary: A 5-year follow up study. Chemosphere 138:718-725

35. Vushe A, Haimene EP, Mashauri D (2014) Namibian Land use changes and nutrient water quality of the Okavango River. J Agric Environ Sci 3:219-239

36. Sawula G (2004) On-site preconcentration and trace metal ions determination in the Okavango Delta water system, Botswana. Talanta 64:80-86

37. Bryan G (1976) Heavy metal contamination in the sea. In: Johnston R (ed) Marine pollution. Academic Press, New York, pp 185-302

38. U.S.EPA. National Recommended Aquatic Life Criteria Table. https://www.epa.gov. Accessed 12 Aug 2019

39. U.S.EPA. Intergrated Risk Information System (IRIS) database. Chemical Assessment National Center for Environmental Assessment. Environmental Protection Agency. https://www.epa.gov/ iris. Accessed 12 Aug 2019

40. U.S.EPA, Regional Screening Level Summary Table (2015) https ://www.epa.gov/risks. Accessed 12 Aug 2019

41. WHO, FAO (2000) Evaluation of certain food additives and contaminants: lead. WHO Food Additives series, World Health Organisation, Geneva

42. Singh UK, Kumar B (2017) Pathways of heavy metals contamination and associated human health risk in Ajay River basin, India. Chemosphere 174:183-199

43. Alexakis $D$ (2016) Human health risk assessment associated with $\mathrm{Co}, \mathrm{Cr}, \mathrm{Mn}, \mathrm{Ni}$ and $\mathrm{V}$ contents in agricultural soils from a Mediterranean site. Arch Agron Soil Sci 62(3):359-373

44. EFSA (2010) Scientific opinion on lead in food. Eur Food Saf Auth $8: 1570$

Publisher's Note Springer Nature remains neutral with regard to jurisdictional claims in published maps and institutional affiliations. 